\title{
Recent analyses of fibre perishables from the Promontory Caves, Utah
}

\author{
by Elizabeth A. Goldberg
}

Recent analyses of the Promontory Caves assemblages by Ives and colleagues (Billinger and Ives 2015; Hallson 2017; Ives 2014; Ives et al. 2014; Reilly 2015) have renewed interest in Julian Steward's (1937) hypothesis that the thirteenth century inhabitants of the Promontory Caves have ties to Northern Dene language-speakers, thus shedding new light on Dene migration and Apachean origins. These studies have largely focused on the similarities between Northern Dene and Promontory moccasins, but other artifact classes - namely fibre perishables - have yet to be examined. This paper synthesizes conclusions drawn from the author's prior research into matting and cordage recovered from the Promontory Caves in comparison to a neighboring Fremont cordage assemblage from the site of Lakeside Cave, with some suggestive differences emerging from material, structure, and knot types. These preliminary results suggest avenues for future comparative analyses of the Promontory perishable artifacts.

The question of when and by which routes Apachean (Southern or Southwestern Dene) ancestors migrated to the American Southwest is difficult to answer. What is agreed upon is that they came from the Dene (Athapaskan) languagespeaking communities of the Subarctic: communities with rich traditions in moccasinmaking (Ives 2014; Ives et al. 2014), cordage (Clark 1974; Cruikshank 1979; Honigmann 1954; McFadyen 1966; McKennan 1959, 1965; Osgood 1936, 1937, 1970, 1971; and Thompson 1972), matting (Honigmann 1954; Osgood 1936, 1940, 1970), and spruce root basketry (Marie and Thompson 2002). No research has been done to examine Apachean fibre perishables, namely perishables made of processed plants fibres and animal fibres (e.g. sinew), to identify if any Northern continuities have persisted, or whether Apachean ancestors completely assimilated the fibre weaving techniques of their neighbors in the

Elizabeth A. Goldberg is a Master's student at the University of Alberta (Department of Anthropology (1315 HM Tory Building, Edmonton, Alberta, T6G 2H4 [egoldber@ualberta.ca]).
Great Basin and the Southwest. Researchers have argued that this assimilation is not unlikely, given that Dene language-speaking groups have a proclivity for adopting the material culture of their neighbors (Ives 2014; Ives et al. 2014). Genetic evidence also indicates that the modern Apachean societies of the Southwest incorporated people from neighboring groups (Ives 2014; Ives et al. 2014; Malhi et al. 2003). Yet, the moccasins from Caves 1 and 2 (42BO1 and 42BO2) of the thirteenth century Great Basin sites of the Promontory Caves, Utah-first excavated by Julian Steward (1937) and later by Ives and colleagues (Billinger and Ives 2015; Hallson 2017; Ives 2014; Ives et al. 2014; Reilly 2015)_reveal a strong connection to Northern Dene language-speakers (Billinger and Ives 2015; Ives 2014; Ives et al. 2014). This suggests that Apachean ancestors, on their journey from the Canadian Subarctic to their present-day location in the American Southwest, may have been present at the site approximately 800 years ago (fig. 1). The exceptional preservation at the 


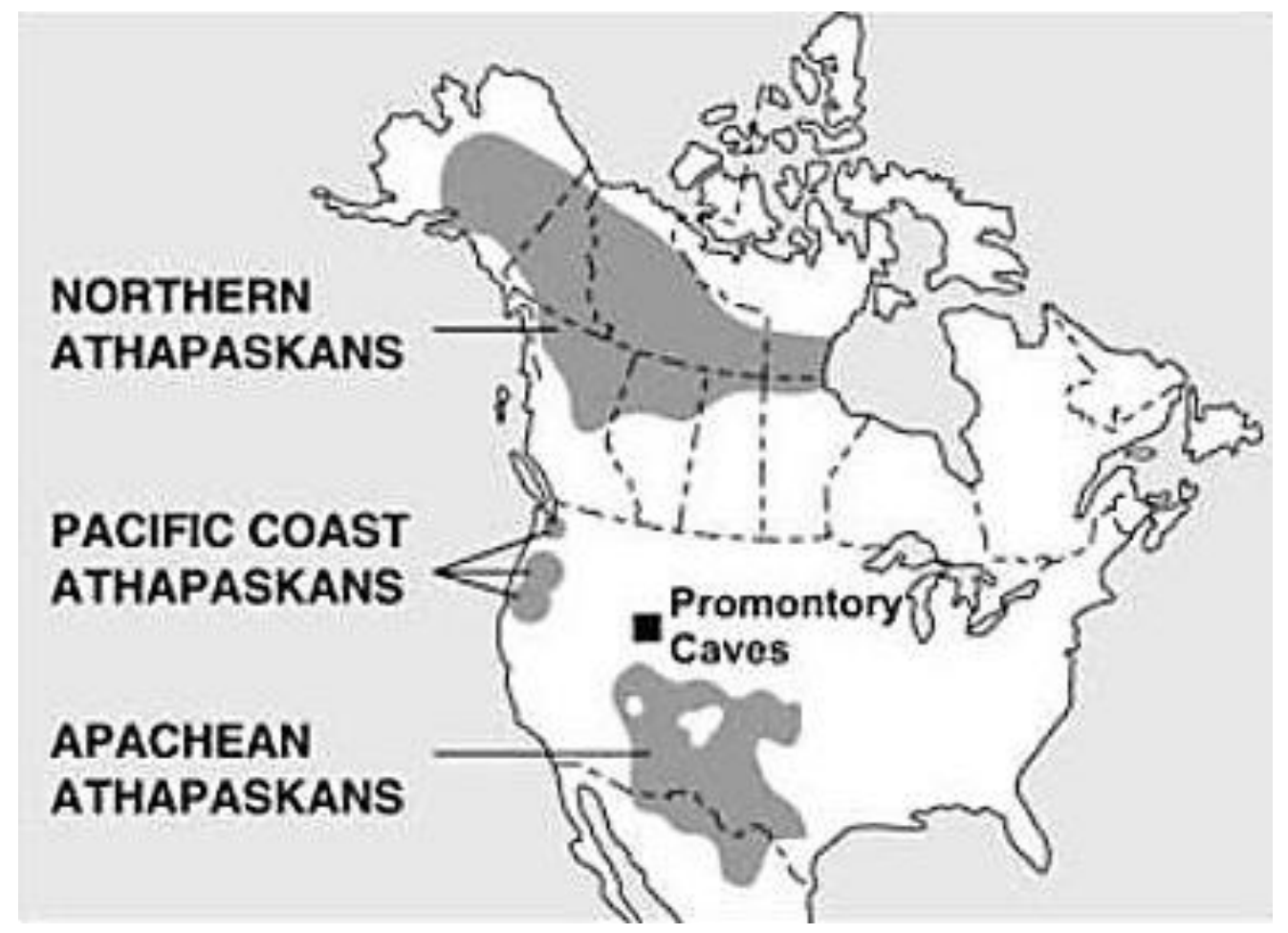

Figure 1. Location of modern Dene (Athapaskan) language-speakers and the Promontory Caves (copied from Billinger and Ives 2015:77).

Promontory Caves has also yielded a large assemblage of well-dated fibre perishables, predominantly from Cave 1, coming from the same site components as the moccasins. Given that the construction of fibre perishables is highly resistant to stylistic change (Adovasio 2010), analysis of this artifact class will help identify the nature of the site's occupants. In particular, similarities to Northern Dene fibre perishables would add further evidence that Apachean ancestors were present at the site in the thirteenth century. A diverse fibre weave assemblage would indicate a complex cultural presence, possibly from the incorporation of neighboring groups. This paper presents a preliminary examination of the Promontory Caves fibre perishable traditions in the form of cordage and matting, followed by comparisons with those of Northern and Southwestern Dene language-speaking groups, to determine both how Southwestern Dene perishable technologies relate to their Northern cousins and if the fibre perishables of the Promontory Caves, like the moccasins, suggest the presence of Apachean ancestors.

\section{Background}

Perishable artifacts are rarely preserved in the archaeological record, but when they are they provide archaeologists with a great deal of information about the people who made them (Adovasio 2010; Hallson 2017). The minute construction attributes of basketry and other complex perishable artifacts, such as moccasins, tend to be culturally conservative and culturally determined, and thus useful in identifying different populations in the archaeological record, along with other lines of evidence (Adovasio 2010). The primary works used in this paper for 


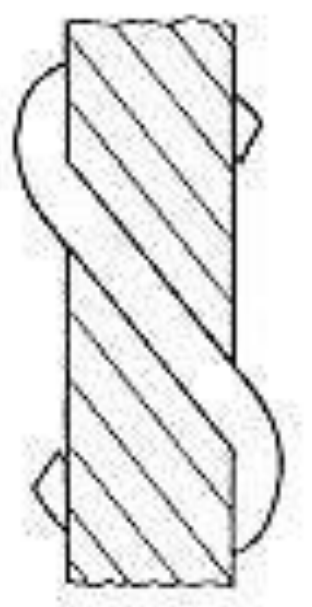

S-twist (入)

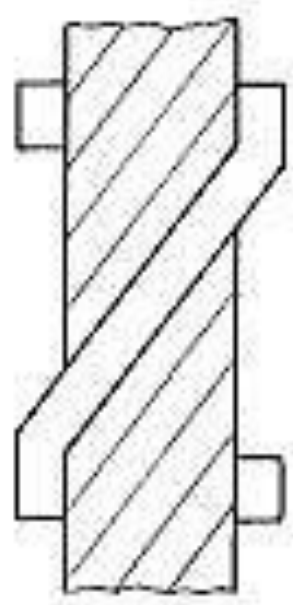

Z-twist (/)

Figure 2. Yarn twist direction (copied from Emery 2009:11).

the analysis of perishable artifacts are Basketry Technology (Adovasio 2010) and The Primary Structures of Fabrics (Emery 2009). This paper focuses specifically on cordage and matting samples from the site of Promontory Cave 1 recovered by Ives and colleagues (Billinger and Ives 2015; Hallson 2017; Ives 2014; Ives et al. 2014; Reilly 2015).

A variety of ethnographic sources were consulted to compile comparative data on the general technological and stylistic attributes of Northern Dene and Southwestern Dene cordage and matting (i.e., Adovasio and Illingworth 2014b; Clark 1974; Cruikshank 1979; Gifford 1940; Honigmann 1954; McFadyen 1966; McKennan 1959, 1965; Osgood 1936, 1937, 1970, 1971; Tanner 1944, 1968, 1982; Thompson 1972; Whiteford 1988). Not discussed in this paper, but of interest to future research, is the Northern Dene tradition of coiled spruce root basketry (Marie and Thompson 2002). Due to the generalized description of many perishable technologies in the literature, the resulting data are uneven but facilitate some broad generalizations about Dene cordage and matting construction and use that are instructive for assessing archaeological materials.

\section{Analysis of Fibre Perishables: Cordage}

The term "cordage" generally refers to a cord or yarn composed of twisted fibres, which are any plant or animal component used in creating fabric (Emery 2009). Fibres are lengthened into yarn through spinning, which can then be plied by twisting two or more yarns together, and re-plied by twisting two or more plied yarns together (Emery 2009). It is these plied yarns that "cordage" often refers to in archaeological reports.

Cordage can be differentiated based on a number of attributes, including its direction of twist, the number of plies, and the material of which it is made (Emery 2009). Twist direction is often the primary differentiator, with cords either S-twist (where fibres slant down from left to right) or Ztwist (fibres slanting up from left to right), as seen in Figure 2. A cord may also contain knots, which can be classified by how they are tied, and 

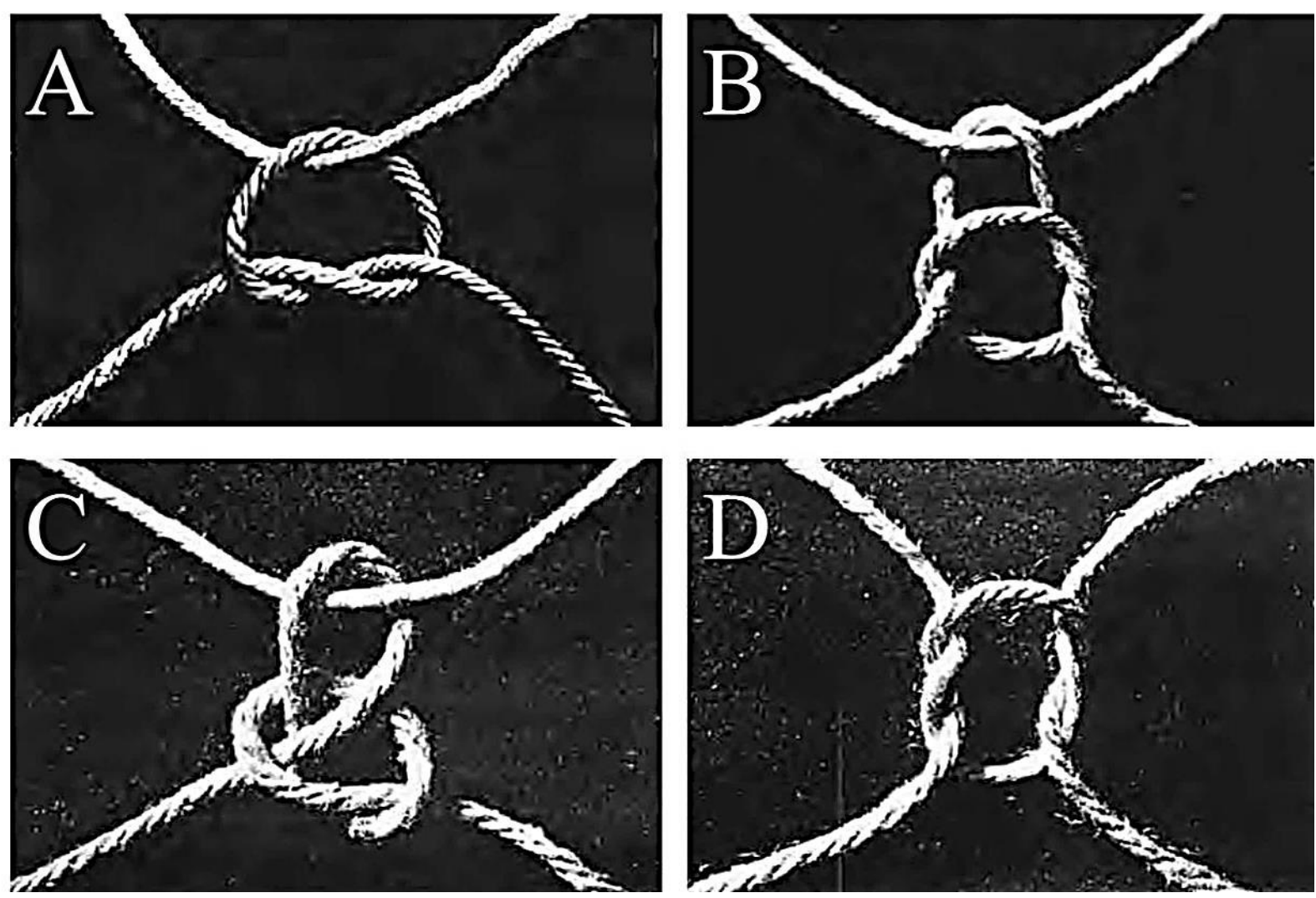

Figure 3. Examples of knots (copied from Emery 2009:34-37).

Figure 3a: Overhand.

Figure 3c: Knotted buttonhole loop.
Figure 3b: Overhand loop (slipknot).

Figure 3d: Square knot. are especially significant in that they may link multiple cords together into nets or reflect composite constructions. However, structures known as knotless netting exist as well, in which cords are held together not by knots but by other structures, including but not limited to a series of loops (Emery 2009). These construction attributes, especially final twist direction, reflect communities of practice and can be strong indicators of cultural similarity and difference. Patterned spatial distributions and changes in the frequencies of final twist direction parametersas well as other construction attributes - can thus be tied to changes in the population in many cases (Carr and Maslowski 1995; Haas 2006; McBrinn and Smith 2006; Minar 2001).
The most common cordage attributes described in the ethnographic literature are material and knot type, which can be broadly indicative of cultural difference and in some cases tied to twist direction. Among the Northern Dene, the Deg Hit'an, Dena'ina, Gwich'in, Han, Kaska, Koyukon, and Tanana have been known to make cords of sinew, rawhide, and babiche (semitanned strips of hide); rabbit and fishskin; feather shafts; spruce roots; willow bark, roots, and bast; grass; nettle; and kelp. Knots used include overhand (fig. 3ab), running noose, square, cowhitches, half-hitches, sheetbend, and knotted loops (fig. 3c) (Clark 1974; Cruikshank 1979; Honigmann 1954; McFadyen 1966; McKennan 1959, 1965; Osgood 1936, 1937, 1970, 1971; 
Thompson 1972). The cordage is twisted with one to three plies or braided with two to four strands. Direction of twist is not mentioned, though examination of ethnographic objects and photos may aid in identifying patterns in future research. Like their northern cousins, the Southwestern Dene have been known to make cords of sinew, rawhide, and willow bark, but did not use babiche, spruce root, or other parts of willow. Southwestern Dene did however also utilize oak, yucca, and buffalo, horse, and human hair fibres in making cords (Gifford 1940; Kluckhohn, Hill, and Kluckhohn 1971), though differences in certain plant and animal materials between Northern and Southwestern Dene may be due to availability. Square knots (fig. 3d) are the most common knot used among the Southern Dene, but granny, half and single bowknot, halfhitch, and overhand loop were not unknown (Gifford 1940; Kluckhohn, Hill, and Kluckhohn 1971). Cordage plies number from one to four and braided strands number from three to eleven, much higher than among the Northern Dene. Direction of twist is not mentioned.

Unfortunately, descriptions of cordage from archaeological contexts focus predominantly on direction of twist and sometimes knot type, and analyses of Fremont cordage are no different. The Fremont culture is an archaeological construct, made up of many peoples with similar material cultures who inhabited the Great Basin from 400 CE to 1300 CE (Adovasio 1979; Adovasio 1986; Madsen and Simms 1998). These are the peoples ancestral Apacheans would have encountered upon entering the Great Basin, and would have interacted with during their occupation of the Promontory Caves. There has been no systematic comparison of Fremont cordage temporally or geographically, which, as Goff (2010) notes, is unsurprising given the ongoing debate on what constitutes Fremont. Hogup Cave, a Fremont site on the western bank of the Great Salt Lake, had largely final Z-twist cordage in its early components, followed by a rise in final S-twist cordage after 650 BCE (Aikens 1970; Goff 2010). Jennings (1957; see also Goff 2010) found only a minor preference for final Z-twist cordage at the Fremont site of Danger Cave, a site east of the Great Salt Lake region and near the UtahNevada border. Goff's (2010) analysis of Fremont cordage from Mantle's Cave in Colorado determined a preference for final Stwist.

Discrepancies in data collection for ethnographic and archaeological cordage makes it difficult to determine where the Promontory Caves cordage fits. Generally speaking, Fremont sites or site components in the Eastern Great Basin with dates close in age to the Promontory Phase (i.e., around the thirteenth century) — such as Mantle's Cave and the later components of Hogup Cave-have predominantly final S-twist cordage (Aikens 1970; Goff 2010; Jennings 1957). Should the cordage of the Promontory Caves 1 and 2 be typical of the region-a description here used hesitantly - the assemblage would have a majority final S-twist. Though the ethnographic literature emphasizes cordage material, this attribute is likely to change over time and space as resource availability changes. However, sinew, rawhide, and willow are used by both Northern and Southern Dene to make cords; the same is true of square, overhand, and halfhitch knots. If these materials are present at the Promontory Caves and absent at neighboring Fremont sites, it may imply a Dene presence.

\section{Analysis of Fibre Perishables: Matting}

The techniques used to construct matting are the same as those for basketry (Adovasio 2010). The primary classification of basketry is its three distinct types of weaves: twining, coiling, and 

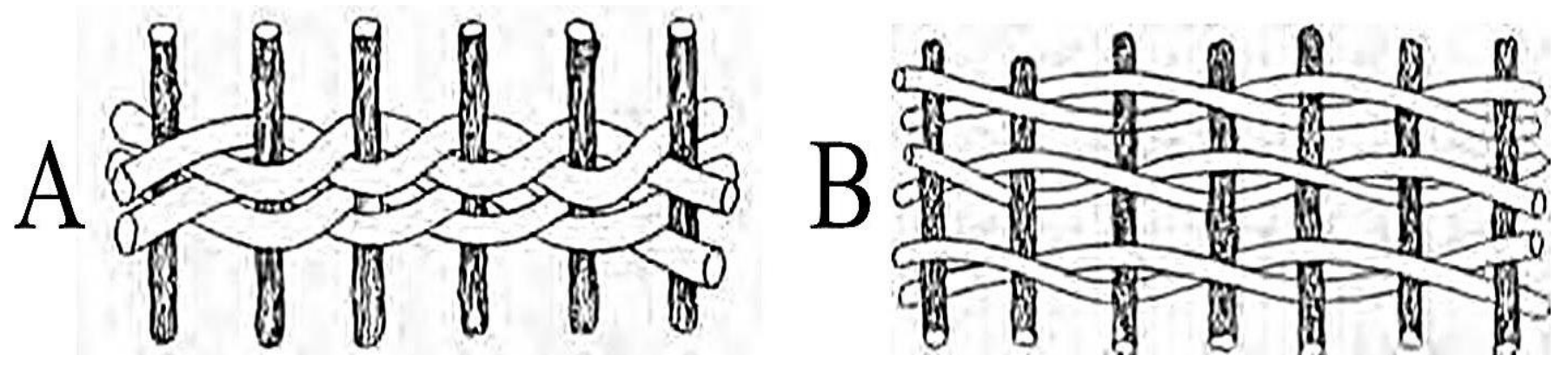

Figure 4a. Close simple twining with S-twisted wefts.

Figure 4b. Open diagonal twining with Z-twisted wefts

(both copied from Adovasio, Pedler, and Illingworth 2002:18).

plaiting (Adovasio 1986, 2010; Driver and Massey 1957). Only twined basketry is expanded on in this paper because it is the sole matweaving technique attested archaeologically in the eastern Great Basin.

Twined basketry is made by moving horizontal wefts around stationary vertical warps (Adovasio 2010). Wefts are often paired or tripled while warps are typically single elements. Different forms of twined basketry can be distinguished by the spacing of their weft rows, the ways wefts and warps engage at each weft crossing, and the stitch slant of the weft rows (Adovasio 2010). Weft rows can be arranged in three basic ways: as close twining, where weft rows lie so close together that the warps cannot be seen; as open twining, where the weft rows are spaced apart so that the warps are visible; and as a mixture of the two. Though there are five ways that wefts can engage warp rows, only two are common. The first is simple twining, where only one warp (or warp unit) is engaged at a time (Adovasio 2010). The other is diagonal twining (or "alternate pair," see Emery (2009)), where alternate warps are engaged at each weft crossing (Adovasio 2010). The only other mode of warp engagement present in this paper's sample is a combination of simple and diagonal twining. The final primary method of classifying twined basketry is the stitch slant of the weft rows, which can either be S-slanted, Z-slanted, or both. The stitch slants are so named because when viewed vertically, the slants resemble the corresponding letter (Adovasio 2010).

While combinations of all these can produce 27 different typologies of twined basketry, only a handful are common: twining that is solely either open or close, of either simple or diagonal twining, and with only S- or Z-twist wefts (fig. 4ab) (Adovasio 2010). Twined basketry can then be further analyzed based on their methods of starting, their selvages or edge finish, splicing, decoration, mending, wear, and raw materials.

Osgood's 1936 work with the Gwich'in mentions matting made by women of willow rods that are "tied together" (1936:67). These mats are used as places to set food and are approximately three feet long. This was only observed among the Gwich'in of Peel River, and not among the other two Gwich'in groups studied. Osgood's account of the Deg Hit'an describes twined grass mats made in the summer by women that were used for sleeping and sitting, as well as wall coverings and doors (1970). Warps are made of twisted grass and wefts are made of twisted willow bark, though sometimes twisted grass is 
used as a weft. Side selvages are of a continuous weft and end selvages are truncated warps. Photographs at the Yale Peabody Museum of mats collected by Osgood show that at least two of these mats were of open simple twining with S-twist wefts (2018). The Deg Hit'an also made mats of braided grass line that were "sewn spirally clockwise with nettle or fish skin line" that can be either rectangular or oval (Osgood 1970:145). On occasion, Deg Hit'an summer houses would be made out of grass mats (Osgood 1970). Honigmann (1954) observed that there was no matting among the Upper Liard and Dease River Kaska.

Kluckhohn, Hill, and Kluckhohn (1971) describe Navajo matting as bundles of grass twined with yucca strips. Lightning mats, small mats used for scaring away lightning, could also be made out of bulrush (Typha sp.). Pictures of Navajo lightning mats housed at the Harvard Peabody Museum show that these mats could be either twined or coiled (2017). Kluckhohn, Hill, and Kluckhohn (1971) also mention some observations by the Franciscan Fathers, who noted that the Navajo made yucca sleeping mats that were circular and woven clockwise, though these descriptions should be taken cautiously. Little is known about Navajo basketry prior to ca. 1880 (Adovasio and Illingworth 2014b; Whiteford 1988). Diagnostic basketry types attributed to the Navajo include varieties of coiled basketry used for ceremonial purposes (Adovasio and Illingworth 2014b; Tanner 1944, 1968, 1982) as well as burden baskets of sumac withes twined around warps made of oak rods (Whiteford 1988). Gifford (1940) lists the presence of checkered weave and twilled weave mats among the Eastern Navajo, which are varieties of plaited basketry and are also present among the Lipan Apache. In addition, Gifford found that Mescalero Apache made sewn mats of tule (1940). Tanner (1944, 1968, 1982) and Whiteford
(1988) describe coiled basketry made by all Apache groups, but that Mescalero and Western Apaches also made twined basketry. No matting is mentioned.

Across North America, twining and plaiting are the preferred techniques for making mats. However, plaiting was unimportant in the eastern Great Basin, and in general Great Basin matting, both ethnographically and archaeologically, was twined (Adovasio 1986; Driver and Massey 1957). Fremont basketry is dominated by coiling, but twining techniques are still present at some Fremont sites in the form of bags or matting. Though there are seven types of twining construction techniques found throughout Fremont sites, only one is common: open diagonal twining with Z-twist wefts (Adovasio 1979). However, the dominance of Z-twist wefts is from the 41 fragments from the Promontory Caves. At other Fremont sites, S-twist wefts are the dominant type. Twining is further limited to Fremont sites in northern Utah and northwestern Colorado (Adovasio, Pedler, and Illingworth 2002; Adovasio and Illingworth 2014a).

Like the cordage, there are significant discrepancies in descriptions of matting from the ethnographic and archaeological record. Ethnographic accounts focus on the material and function of the mats, while archaeological analyses focus on matting typologies. Interestingly, Northern and Southern Dene matting contain examples of coiled mats as well as twined mats made of grass. The Promontory Caves 1 and 2 produced only twined matting, but perhaps the presence of coiled mats at other sites with a Promontory Phase could indicate a Dene presence. In relation to neighboring Fremont sites, an Ancestral Apache presence would be indicated at the Promontory Caves through subtle differences in artifact construction, suggesting ancestral Apachean learners of local styles. There is also the possibility that, in the absence of 
obvious Dene basketry traits, Southern Dene ancestors were intermarrying with local Fremont women, who then made Fremont-looking basketry. For the purposes of this paper, twined analysis will be restricted to twining typologies based on availability of the data.

\section{Research Goal and Methods}

The goal of this study is to begin to synthesize prior research of cordage and matting from the Promontory Caves and examine similarities and differences in construction attributes to those of Northern and Southwestern Dene languagespeakers in the ethnographic record. This goal was approached through the analysis of 99 cordage fragments from Ives' excavations at Promontory Caves, along with a comparative sample of 21 cordage fragments from the Fremont site of Lakeside Cave (42BO385) (Andrews, Adovasio, and Whitley 1988), chosen for its physical proximity to the Promontory Caves and its well-dated artifacts. Analysis of fibre materials made by modern Dene peoples is limited to what is available in the literature (Clark 1974; Cruikshank 1979; Gifford 1940; Honigmann 1954; Kluckhohn, Hill, and Kluckhohn 1971; McFadyen 1966; McKennan 1959, 1965; Osgood 1936, 1937, 1970, 1971; Tanner 1944, 1968, 1982; Thompson 1972; Whiteford 1988). Hence, only the most commonly described attributes were useful for the purposes of this paper: for cordage, final twist direction, knot type, and material (though all attributes were recorded for the samples that underwent analysis, the following methods detail only what was used for attributes relevant to this paper); for matting, the general construction typologies of twining (close versus open, simple versus diagonal, and S-twist (fig. 4a) versus Ztwist wefts (fig. 4b)).

\section{Fibre Perishables from the Promontory Caves}

The dryness of the Promontory Caves allowed for extensive preservation of perishable artifacts rarely found at other archaeological sites (Steward 1937). Such exceptional preservation allows archaeologists a glimpse at past lifeways impossible to infer from stone tools, including the lives of women, whose work with hide and fibre materials rarely survives the ravages of time (Hallson 2017; Reilly 2015). The 353 moccasins from both Steward's (1937) and Ives' (Hallson 2017; Ives et al. 2014) excavations have received the most archaeological attention of the perishable assemblage, but they are hardly the only perishable class of note. Below, the cordage and matting portions of the perishable assemblage are discussed.

Seventy-six cords and one netting fragment were recovered during Steward's original excavations of Caves 1 and 2, with 144 more recovered during the excavations undertaken by Ives and colleagues (Hallson 2017; Steward 1937). Of the matting, 41 fragments were recovered from Steward's original excavations, each one likely coming from a different mat (Hallson 2017; Steward 1937). Nine more fragments were recovered under the excavations of Ives and colleagues (Hallson 2017; Ives 2014; Ives et al. 2014). When compared along with the cordage to fibre perishables in the Dene ethnographic record and the archaeological record of the Great Basin, some preliminary conclusions can be drawn about the nature of the occupants of Caves 1 and 2.

\section{Cordage Analytical Procedures}

I examined and analyzed the cordage samples from the Promontory and Lakeside Caves at Mercyhurst University in the spring of 2017 under the guidance of Dr. E. Jolie, Mercyhurst 
University. Each cord was analyzed on a fresh sheet of acid-free tissue paper. All instruments used to analyze the cords were sterilized before and between each use. Probes and tweezers were immersed in a Steri 250 dry bead sterilizer heated to approximately $250^{\circ} \mathrm{C}$ for ten seconds to clean them of any adhering organic matter. Since not every tool could be placed in the dry bead sterilizer, acid-free tissue paper dipped in isopropyl alcohol was used to clean the 799A Starrett caliper tips and the measuring tape between each analysis. Since at the time there was interest in obtaining human DNA from the artifacts, to prevent contaminating the cords with my own DNA, a hair net, surgical mask, and nitrile gloves were worn and changed after every analysis. Tweezers and probes were used to investigate the construction of tightly woven elements.

The Promontory and Lakeside Caves cordage specimens were allocated to structural types based on the number and composition of plies (1, 2, or more; simple or compound); direction of initial spin ( $S$ or $Z$ ); and direction of final twist ( $S$ or Z), if present. Written shorthand notation of ply spin and twist parameters followed protocol outlined in Haas (2006), beginning with the number of plies, followed by the initial spin in a lowercase letter, and ending with the direction of final twist in an uppercase letter. For example, two-ply z-spun cordage with a final S-twist is recorded as $2 \mathrm{zS}$. In cases where cordage was replied, parentheses encase the shorthand notation for initial levels of construction. So, if two plies of $2 \mathrm{zS}$ cordage were re-plied $\mathrm{Z}$-wise the notation would read $2(2 \mathrm{zS}) \mathrm{Z}$. In the case of braided cords the number of strands was counted. If said strands were twisted, twist direction was also determined in addition to other measurements mentioned previously. Knots were recorded and identified following Emery (2009) without being untied. Instead, and as necessary, the pathways of the cord(s) engaged in the knots were traced, sketched, and replicated using modern commercial cotton string. For specimens with multiple knots, the distance between knots was measured. Photographs were taken of select specimens to highlight unique structural details. Where possible, plant materials used in the Promontory Caves cordage were tentatively identified through comparison with known specimens and based on Dr. E. Jolie's personal experience. All contextual information and recorded attributes were placed directly in an Excel spreadsheet adapted from standardized analysis forms in use at Mercyhurst University's Perishable Artifact Laboratory.

\section{Results}

A total of 120 cordage specimens were examined in this study. Ninety-nine of those reflect a sample from excavations by Ives and colleagues (Hallson 2017) from the Promontory Phase deposits at Caves 1, dated between 662 and 826 radiocarbon years before present (BP) (Ives et al. 2014), while 21 come from Lakeside Cave's Fremont deposits, bracketed by radiocarbon dates suggesting an age of 1310 to 2150 years BP (Adovasio and Illingworth 2000; Andrews, Adovasio, and Whitley 1988). At both sites, bast fibre (such as Apocynum sp.) was the primary material used for cordage construction (fig. 5). However, the Promontory Caves sample is notable for having hide/skin and fur cords while Lakeside Cave yielded none. Lakeside Cave also had a slightly higher concentration of bark cords (either Artemisia sp. or Juniperus sp.) (table 1). Visual inspection permitted identification of bast fibre (Apocynum sp. and Asclepias sp.) and processed bark (Artemisia sp. or Juniperus sp.) in the assemblage. No attempt was made to identify the sources of the hide/skin and fur cords, except that one cord has feather barbules that are 


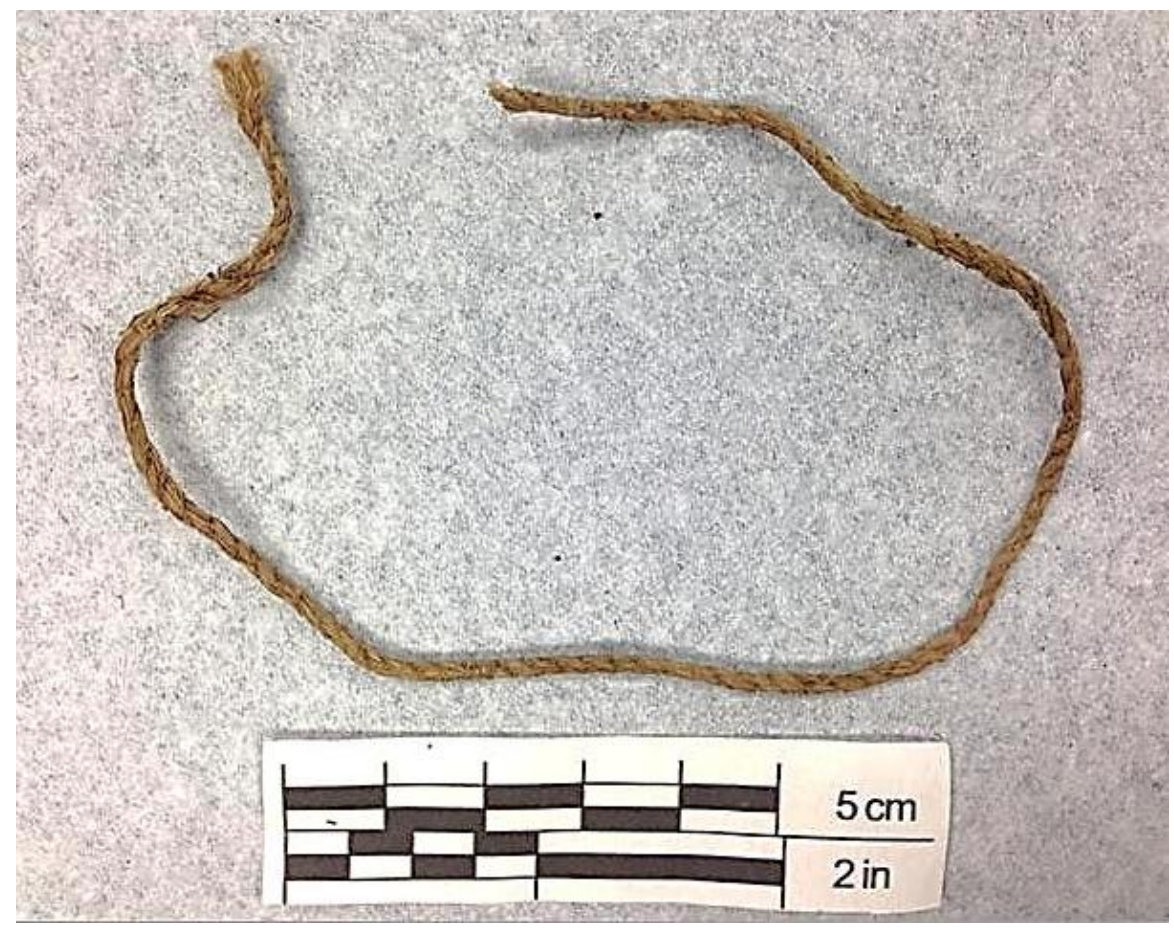

Figure 5. FS 204 from Promontory Cave 1, an example of a final Z-twist cord made of bast fibre. Photo by E. Goldberg.

Table 1. Cordage Raw Materials at the Promontory and Lakeside Caves.

\begin{tabular}{lccccc}
\hline Site & $\begin{array}{c}\text { Bast } \\
\text { fibre }\end{array}$ & Bark & Hide/skin & Fur & Total \\
\hline Promontory Caves 1 & 81 & 1 & 16 & 1 & 99 \\
Lakeside Cave & 18 & 3 & 0 & 0 & 21 \\
Total & 99 & 4 & 16 & 1 & 120 \\
\hline
\end{tabular}

Table 2. Comparison of cordage knots at Promontory and Lakeside Caves.

\begin{tabular}{lccccccccc}
\hline Site & Overhand $\begin{array}{c}\text { Overhand } \\
\text { Loop }\end{array}$ & Square & Granny & $\begin{array}{c}\text { Half- } \\
\text { hitch }\end{array}$ & Thief & Other & Total \\
\hline Promontory Caves 1 & 39 & 14 & 0 & 0 & 0 & 0 & 0 & 53 \\
Lakeside Cave & 10 & 0 & 2 & 1 & 1 & 1 & 1 & 16 \\
Total & 49 & 14 & 2 & 1 & 1 & 1 & 1 & 69 \\
\hline
\end{tabular}




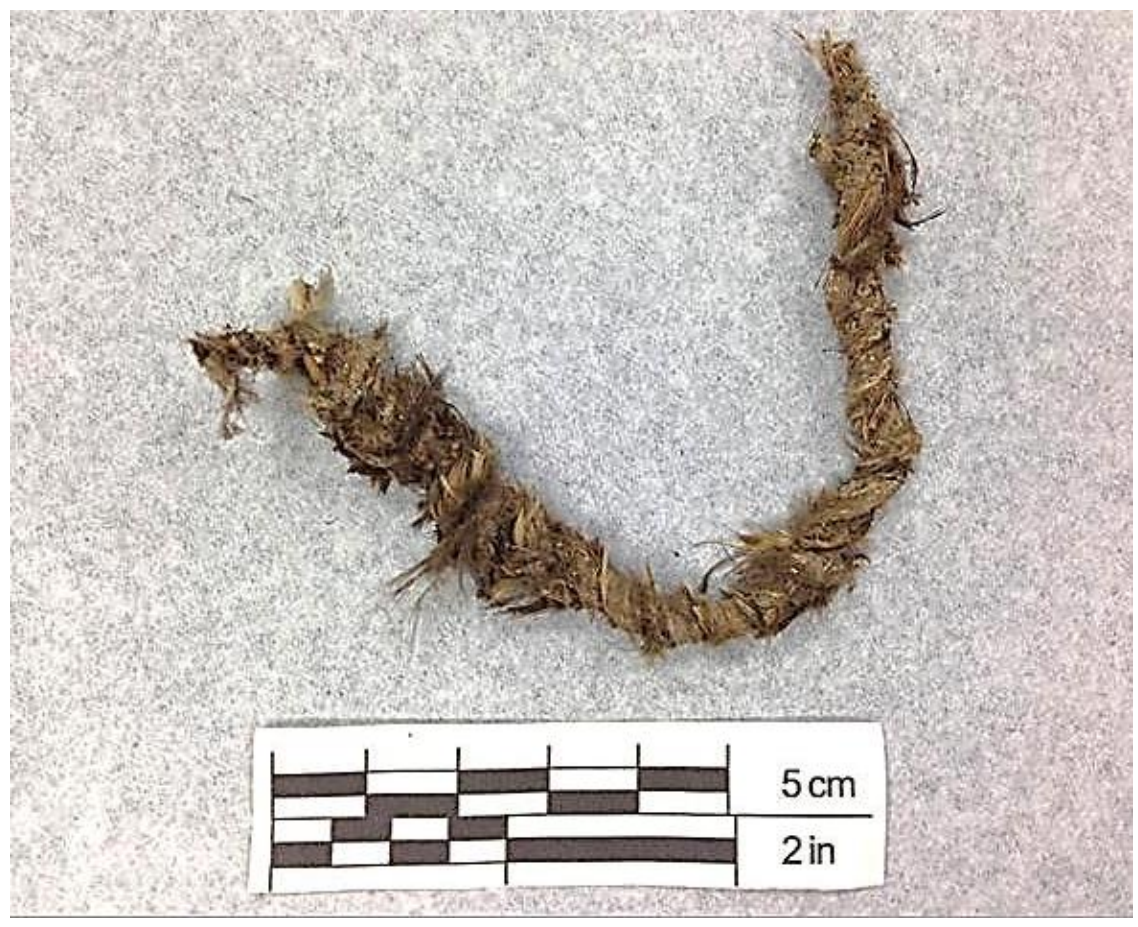

Figure 6. FS 693 from Promontory Cave 1, feather-wrapped cord. Photo by E. Goldberg.

consistent with an unidentified bird's skin. The other hide/skin cords are likely mammalian in origin, and are possibly bison (Bison bison) given the abundance of bison remains recovered from the site. Small sample sizes and the preference for bast fibre at both sites make it difficult to recognize any meaningful patterns in cordage construction.

Of the 99 specimens from the Promontory Caves, 49 are knotted, with a total of 53 knots. At Lakeside Cave, 12 of the 21 specimens were knotted, yielding a total of 16 knots. Overhand is the most common knot type at both sites. The Promontory Caves, though, show less variety of knots than Lakeside Cave, with overhand loop being the second most frequent knot type. Lakeside Cave's knot diversity encompasses square, granny, half-hitch, thief, and unidentified types, with no overhand loops (table 2). Also of interest is that a significant number of the knots from the Promontory Caves occur at the ends of cords - 19 out of 42 knotted artifacts — or as part of an overhand loop. Together, that is 31 out of 42 knotted artifacts, or over 70 percent of the knotted cordage in the sample assemblage.

At both sites, the majority of cords exhibit a final S-twist. Wrapped and braided cords are present only at the Promontory Caves (table 3). The majority of the cords at both sites are twisted. Two ply z-spun, final S-twist $(2 z S)$ is the most common at both sites, followed by two ply sspun, final Z-twist, as in Figure 5 (2sZ). The Promontory Caves, however, has a greater variety of twisted constructions than Lakeside Cave (table 4). Lakeside Cave has no wrapped cords, but the Promontory Caves produced six (fig. 6). The Promontory Caves sample assemblage also included five artifacts of unmodified, unidentified wood (FS\#s 178, 258, 259, and 313a and b) wrapped with sinew. Specimens $313 \mathrm{a}$ and $\mathrm{b}$ have knotted lengths of sinew cord extending from them. 
Goldberg Fibre Perishables from the Promontory Caves, Utah

Table 3. Summary Cordage Final Twist Data from the Promontory and Lakeside Caves.

\begin{tabular}{lccccccc}
\hline Site & $\begin{array}{c}\text { Final S- } \\
\text { twist }\end{array}$ & $\begin{array}{c}\text { Final Z- } \\
\text { twist }\end{array}$ & $\begin{array}{c}\text { Final S- and } \\
\text { Z-twist }\end{array}$ & Unspun & Wrapped & $\begin{array}{c}\text { 3-strand } \\
\text { Braid }\end{array}$ & Total \\
\hline $\begin{array}{l}\text { Promontory } \\
\text { Caves 1 }\end{array}$ & 60 & 28 & 0 & 7 & $3 *$ & 1 & 99 \\
$\begin{array}{l}\text { Lakeside Cave } \\
\text { Total }\end{array}$ & 17 & 2 & 1 & 1 & 0 & 0 & 21 \\
\cline { 2 - 8 } & 77 & 30 & 1 & 8 & 3 & 1 & 120 \\
\hline
\end{tabular}

* The number shown here consists only of untwisted strands with wrapping. There are three cords within the twisted categories that are wrapped, and two within the unspun category that are wrapped.

Table 4. Twisted Cordage Structural Types from the Promontory and Lakeside Caves.

\begin{tabular}{lcccccccc}
\hline Site & $\mathbf{S}$ & $\mathbf{Z}$ & $\mathbf{2 S}$ & $\mathbf{2 z S}$ & $\mathbf{2 s Z}$ & $\mathbf{2 s Z}$ and $\mathbf{2 Z S}$ & $\mathbf{6 s Z}$ & Total \\
\hline Promontory Caves 1 & 11 & 9 & 1 & 48 & 18 & 0 & 1 & 88 \\
Lakeside Cave & 0 & 0 & 0 & 17 & 2 & 1 & 0 & 20 \\
Total & 11 & 9 & 1 & 65 & 20 & 1 & 1 & 108 \\
\hline
\end{tabular}

Table 5. Cordage raw materials at the Promontory Caves and Lakeside Cave compared to those of Dene language-speakers.

\begin{tabular}{lcccc}
\hline Site & $\begin{array}{c}\text { Bast } \\
\text { fibre }\end{array}$ & Bark & Hide/skin & Fur \\
\hline Promontory Caves 1 & $\mathrm{x}$ & $\mathrm{x}$ & $\mathrm{x}$ & $\mathrm{x}$ \\
Lakeside Cave & $\mathrm{x}$ & $\mathrm{x}$ & & \\
Northern Dene & $\mathrm{x}$ & $\mathrm{x}$ & $\mathrm{x}$ & \\
Southern Dene & & $\mathrm{x}$ & $\mathrm{x}$ & $\mathrm{x}$ \\
\hline
\end{tabular}

\section{Matting}

There were 41 fragments of matting recovered from Steward's original 1937 excavations. All of these fragments are twined (Steward 1937). Eight of the mat fragments are of simple open twining, of which seven have Z-twisted wefts and only one has an S-twisted weft. The remaining 33 mat fragments are all diagonally twined. Thirty-one of these are open-twined with a Z-twist weft. Two are close-twined with an S-twisted weft (Adovasio, Pedler, and Illingworth 2002).

\section{Discussion}

If the cordage and matting of the Promontory Caves were made by ancestral Apachean populations, diagnostic attributes might be the same as those from the Northern and Southwestern Dene ethnographic record. Though the sample of Fremont cordage from Lakeside Cave is small and represents a significantly earlier occupation, it lacks any hide cords, which form approximately one-sixth of the Promontory Caves 1 and 2 cordage sample. The Promontory 
Table 6. Comparison of cordage knots made by Dene language-speakers and inhabitants of the Promontory Caves

\begin{tabular}{|c|c|c|c|c|c|c|c|c|c|}
\hline Site & Overhand & $\begin{array}{l}\text { Overhand } \\
\text { Loop }\end{array}$ & Square & Granny & $\begin{array}{l}\text { Half- } \\
\text { hitch }\end{array}$ & $\begin{array}{l}\text { Cow- } \\
\text { hitch }\end{array}$ & Sheetbend & $\begin{array}{c}\text { Running } \\
\text { noose }\end{array}$ & Bow \\
\hline $\begin{array}{l}\text { Promontory } \\
\text { Caves } 1\end{array}$ & $\mathrm{x}$ & $\mathrm{x}$ & & & & & & & \\
\hline $\begin{array}{l}\text { Northern } \\
\text { Dene }\end{array}$ & $\mathrm{x}$ & $\mathrm{x}$ & $\mathrm{x}$ & & $\mathrm{x}$ & $\mathrm{x}$ & $\mathrm{x}$ & $\mathrm{x}$ & \\
\hline $\begin{array}{l}\text { Southern } \\
\text { Dene }\end{array}$ & & $\mathrm{x}$ & $\mathrm{x}$ & $\mathrm{x}$ & $\mathrm{x}$ & & & & $\mathrm{x}$ \\
\hline
\end{tabular}

Caves do share these sinew/hide cords with Northern and Southwestern Dene as well, as shown in Table 5, but the use of hide/sinew cords is widespread throughout North America and thus cannot specifically be attributed to Dene language-speakers (Driver and Massey 1957; Honigmann 1954; McKennan 1965; Osgood 1936, 1970, 1971). The same is true of other Promontory Caves cordage materials not found at Lakeside, such as quillwork, fur, and bird skin (Driver and Massey 1957; Osgood 1936; Steward 1937; Thompson 1972). However, overall, the cordage materials from the Promontory Caves 1 and 2 are more diverse than those from Lakeside.

Twist direction yields similar results: both sites have a majority of twisted cords that are two-ply, z-spun, with a final S-twist. The Promontory assemblage, however, has a greater incidence of final Z-twisted cords than Lakeside, with final Z-twist cords forming approximately one-fourth of the Promontory assemblage and one-tenth of the Lakeside assemblage. In addition, a little more than one-fifth of the twisted Promontory cords have only a single ply, while all of the Lakeside cords are two-ply. These differences between the Promontory and Lakeside materials may be informative of function; a larger sample size is needed to better determine this.
The types of knots found in each assemblage may also be indicative of different functions for the cords at the Promontory and Lakeside sites. The knots found on cords from Ives and colleagues' excavations (Hallson 2017) are all overhand or overhand loop, while only about three-fifths of the knots on Lakeside cordage are overhand. The rest of Lakeside's knot types are a broad variety represented only by one or two examples of each. Although the Promontory Caves 1 and 2 share the making of overhand knots with both Northern and Southern Dene, as shown in Table 6, it is not a diagnostic enough knot type to definitively attribute the assemblage to Dene language-speakers. Rather, it is the heavy preference for overhand knots at the Promontory Caves in comparison to the broad and varied knot assemblage at Lakeside that suggests differences in function and population between the two sites.

Similar to the present study, Steward's cordage sample also demonstrated a heavy majority of overhand knots, occurring "on nearly every fragment of cord" (Steward 1937:36). Overhand knots also occur on a woven fragment analyzed by Steward, used to fasten together cordage (Steward 1937). This piece of weaving appears to be knotted looped fabric (Emery 2009). It is possible that, if broken apart, such a 


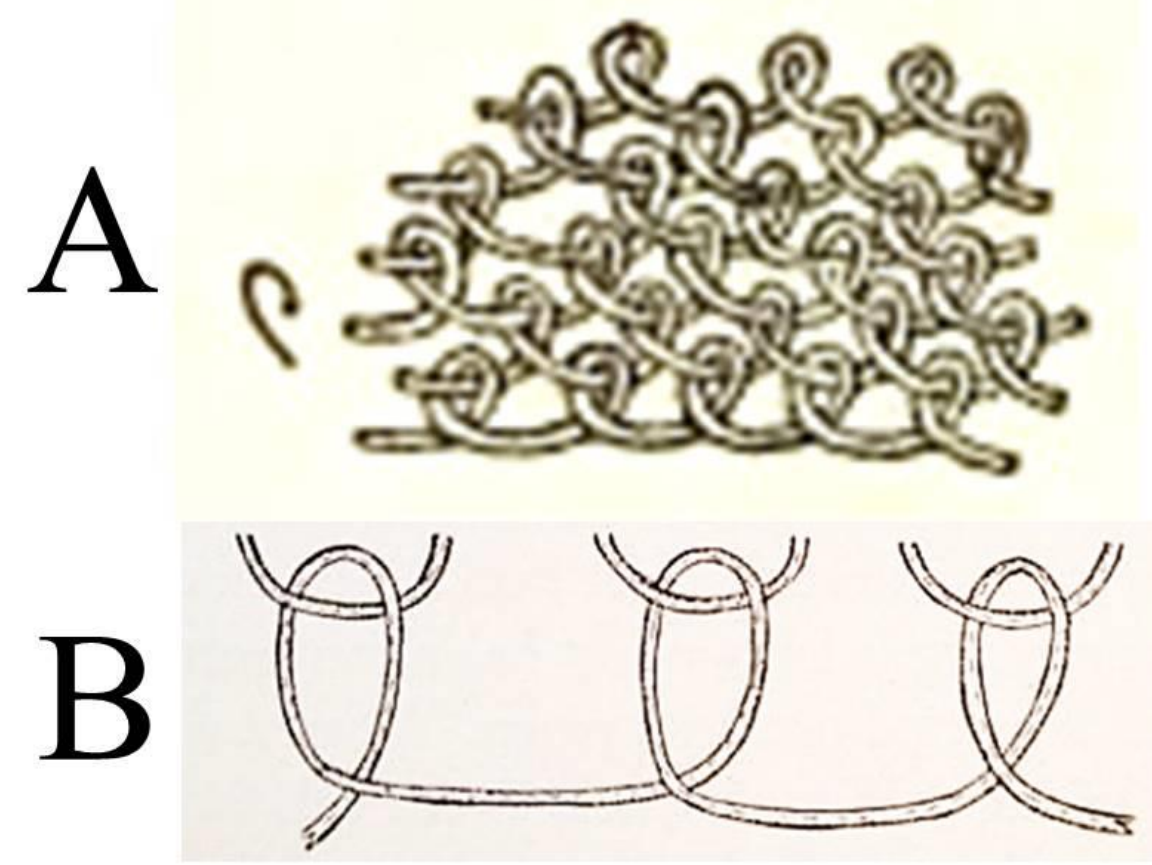

Figure 7a. Simple looping from the Promontory Caves (copied from Steward 1937:34).

Figure 7b. Gwich'in rabbitskin weaving. Note the similarity to the simple looping from the Promontory Caves (copied from Osgood 1936:72).

structure may not be recognizable in an archaeological assemblage. Given that the overhand knots and loops from the recent excavations at Promontory occur mostly at the ends of cords, these cords could once have been part of a similar piece of knotted looping, now fragmented after reaching the end of its use-lifeas the frugality of Promontory's inhabitants resulted in artifacts being repaired and re-used until this was no longer possible (Billinger and Ives 2015). As for overhand loops, there is a possibility that these knots are actually knotted buttonhole loops, a type of looping used in knotless netting. Though the excavations done by Ives and colleagues have not revealed any nets (Hallson 2017), Steward's sample does contain one instance of simple looping, shown in Figure 7 , which is unique among archaeological assemblages in the eastern Great Basin (Steward 1937). Interestingly, simple looping is found in the Subarctic among Northern Dene languagespeakers (fig. 7), and since it is not common in the Eastern Great Basin, may imply a connection between them and the people who formed the Promontory Phase assemblage (Driver and Massey 1957).

Another artifact type of interest that may inform on function-based material preference is the instances of unmodified pieces of wood or twigs wrapped with hide or sinew (fig. 8). Steward had found similar artifacts during his excavations, which he termed as "rough splinters" (1937:22), and could offer no conclusive explanations as to their function, except perhaps once-feathered darts. However, the only similarity between these wooden splinters and 


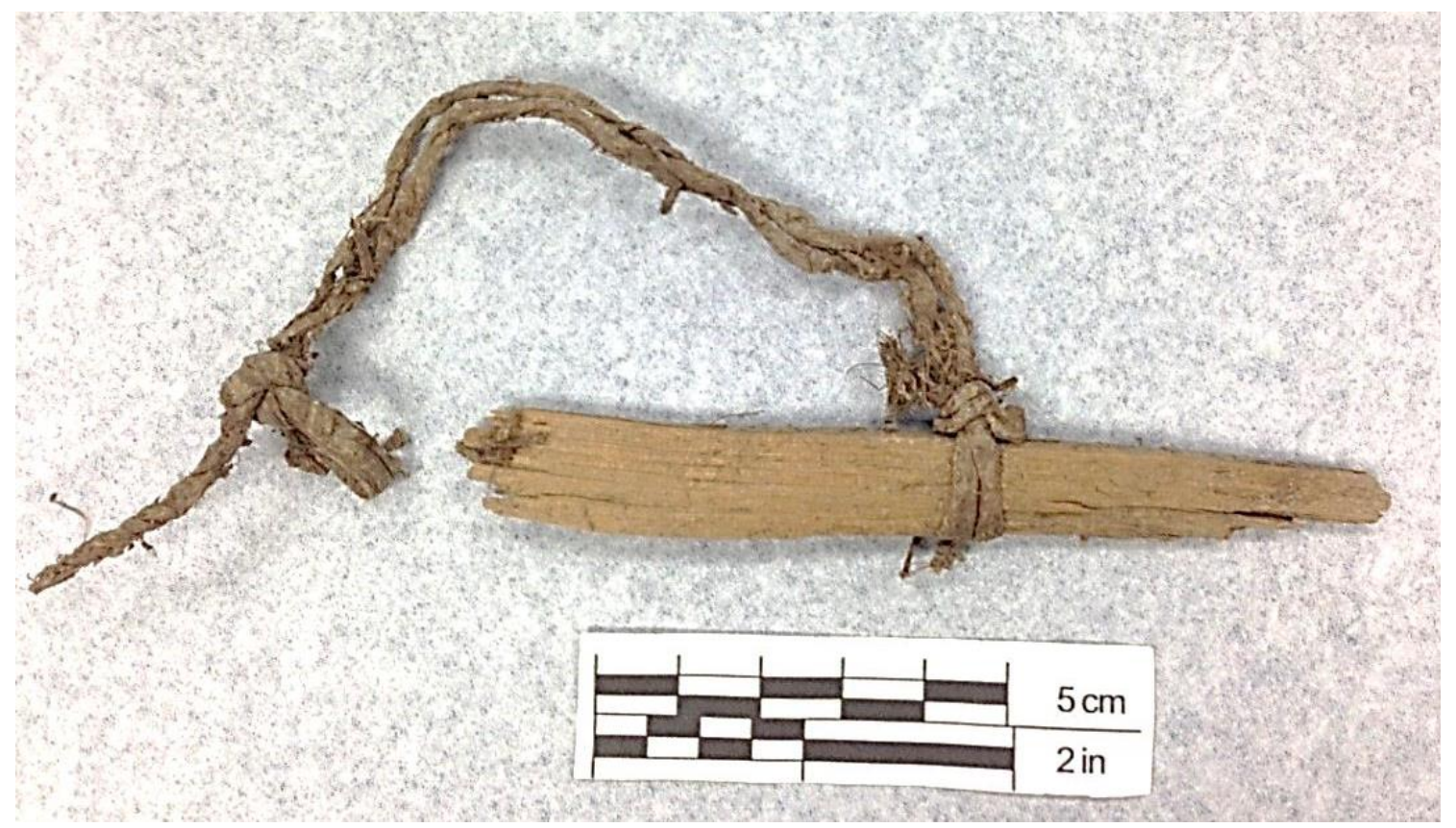

Figure 8. FS 313a, unmodified wood with hide cord. Photo by E. Goldberg.

these feathered darts is their appearance; there is nothing to indicate the splinters were once feathered (Steward 1937). The two unmodified pieces of wood with lengths of twisted sinew extending from them may be snare parts, but as with Steward's conjecture, this is said more from lack of a better explanation than any certainty. These pieces of wood bear little resemblance to subsistence technologies used in the eastern Great Basin, such as deadfall traps associated with the so-called Promontory Pegs (Janetski 1979; Wylie 1974), or pieces depicted in illustrations of Dene snares and traps (Cooper 1938). Examinations of Apache material culture (Gifford 1940) likewise yielded no direct analogies, though it is noteworthy that these constructions appear to be expedient or even unfinished.

The matting of the Promontory Caves is difficult to characterize in relation to ethnographic accounts of matting, which focus on material and function rather than structural attributes. It is also difficult to compare
Promontory Caves' matting to other Great Basin archaeological assemblages, as mat fragments and basket wall fragments are difficult to distinguish. This does not prevent one significant observation pertaining to the weft twist direction of matting in the Great Basin. Adovasio (1979) characterizes the twining techniques of neighboring Fremont populations as predominantly Z-twisted. However, his analysis includes the Promontory Caves as a Fremont site, and when Promontory is removed from consideration, the most common weft twist direction at Fremont sites in this region is $\mathrm{S}$ twisted.

\section{Conclusions and Future Research}

The cordage sample from the Promontory Caves 1 and 2 has some interesting discrepancies from that of Lakeside Cave. Firstly, there are materials present at the Promontory Caves not used at Lakeside - namely hide, but also quillwork, fur, 
and bird skin — despite both sites sharing a heavy preference for bast fibre. The number of plies and twist direction of the cordage also reveal intriguing differences; although both sites share a majority of two-ply, z-spun, final S-twisted cords, a greater fraction of final Z-twist at Promontory and complete absence of single-ply cords at Lakeside may be indicative of differences in the way cords were used by their respective populations. This is supported by the differences in knot types used between the two sites, with the Promontory Caves' knots consisting solely of overhand and overhand loop knots and Lakeside sporting a much wider variety. The further possibility that the abundance of overhand knots at the Promontory Caves, particularly those that occur at the ends of cords, are fragments of a larger construction like the knotted looped fabric recovered by Steward (1937), as well as the possibility that the overhand loops were once part of a knotless net unique in Great Basin archaeological assemblages, are highly suggestive of a non-Fremont presence at the Promontory Caves. The component most indicative of a nonFremont presence at Promontory, however, lies in the matting structures recovered from Caves 1 and 2. The fact that the characterization of Fremont matting as mostly Z-twisted wefts in the Eastern Great Basin is entirely due to the Promontory Caves matting assemblage, and that, when taken out of consideration, Fremont matting has a majority of S-twisted wefts, strongly suggests that there was a separate population inhabiting the Promontory Caves.

However, attempts to tie the cordage and matting recovered from the Promontory Caves 1 and 2 to modern Northern and Southern Dene populations have proven inconclusive. Direct research with perishable artifacts from Dene ethnographic collections is needed before a connection with the Promontory cordage and matting assemblages can be proven or disproven. Though inconclusive, this does not hinder the fact that the cordage and matting assemblages from the Promontory Caves suggest a population presence other than Fremont.

The rest of the cordage assemblage uncovered at the Promontory Caves site still needs to be analyzed, in addition to a reanalysis of Steward's data, including cordage found as part of composite artifacts such as clothing or basketry. Of interest to the researcher is a more in-depth comparison between dimensions of variation within the cordage assemblage as well as more thorough inter-site comparisons, both within the context of the Great Basin (particularly with sites contemporary to the Promontory Phase at the Promontory Caves 1 and 2) and with the material culture of the Northern and Southwestern Dene. In so doing, perhaps a greater understanding of the relationship between the fibre perishable technologies of Northern and Southwestern Dene, and the place of the Promontory Caves site, can be achieved.

\section{Acknowledgements}

There are many people who helped make this work possible. Thank you to the continued patience and advice from the editors and reviewers of Compass, who kindly read this paper in its early stages; thank you to my friends and fellow students at the University of Alberta, who always made me feel welcome; thank you to Dr. Jack Ives, for allowing me to work with the cordage from the Promontory Caves, and subsequently taking me on as a student; thank you to Dr. Ed Jolie, who introduced me to a love of perishable artifacts and guided me through my first forays into academic research; thank you to the rest of the Anthropology/Archaeology Department at Mercyhurst University, who have aided me in countless ways; and last but certainly not least, thank you to my parents, for everything. 


\section{References Cited}

Adovasio, J. M. 1979. Comment by Adovasio. American Antiquity 44(4):723-731.

- 1986. Prehistoric Basketry. In Handbook of North American Indians, Volume 11: Great Basin, edited by W. L. d'Azevedo, pp. 194-205. Smithsonian Institution Press, Washington, D.C.

- 2010. Basketry Technology. Updated edition. Left Coast Press, Walnut Creek, California.

Adovasio, J. M., D. R. Pedler, and J. S. Illingworth. 2002. Fremont Basketry. Utah Archaeology 15:5-26.

Adovasio, J. M. and J. S. Illingworth. 2000. The Evolution of Plant Fiber Artifact Manufacture in the Eastern Great Basin: A Turn of the Millennium Perspective. Paper presented at the $27^{\text {th }}$ Great Basin Anthropological Conference, Ogden, Utah.

- 2014a. Fremont Basketry, Yet Again! Paper presented at the Great Basin. Anthropological Conference, Boise, Idaho.

- 2014b. Perishable Industries from Glen Canyon: An Affiliation Report. Mercyhurst University. Submitted to Bureau of Reclamation, Upper Colorado Regional Office, Agreement No. R11AP40091.

Aikens, C. Melvin. 1970. Hogup Cave. University of Utah Anthropological Papers, No. 93. University of Utah Press, Salt Lake City.

Andrews, R. L., J. M. Adovasio, and T. G. Whitley. 1988. Coiled Basketry and Cordage from Lakeside Cave (42BO385), Utah. Paper prepared for the 21st Annual Great Basin Conference, October 6-8, 1988, Park City, Utah.

Billinger, Michael and John W. Ives. 2015. Inferring Demographic Structure with Moccasin Size Data from the Promontory Caves, Utah. American Journal of Physical Anthropology 156:76-89.

Carr, Christopher and Robert F. Maslowski. 1995. Cordage and Fabrics. In Style, Society, and Person, edited by Christopher Carr and Jill E. Neitzel, pp. 297-343. Plenum Press, New York and London.

Clark, Annette McFadyen. 1974. Koyukuk River Culture. Canada. National Museum of Man. Mercury Series, Ethnology Service Paper 18. National Museums of Canada, Ottawa.

Cooper, John M. 1938. Snares, Deadfalls, and Other Traps of the Northern Algonquians and Northern Athapaskans. The Catholic University of America Anthropological Series 5. The Catholic University of America, Washington D.C.

Cruikshank, Julie. 1979. Athapaskan Women: Lives and Legends. Canada. National Museum of Man. Mercury Series. Ethnology Service Paper 57. National Museums of Canada, Ottawa.

Driver, Harold E. and William C. Massey. 1957. Comparative Studies of North American Indians. Transactions of the American Philosophical Society 47(2):165-456.
Emery, Irene. 2009. The Primary Structures of Fabrics. Thames and Hudson, New York.

Gifford, Edward W. 1940. Culture Element Distributions XII: Apache-Pueblo. Anthropological Records 4(1). University of California Press, Berkeley.

Goff, Sheila. 2010. A New Look at Fremont Cordage from Mantle's Cave in Northwest Colorado. Kiva 76 (1):3354.

Haas, W. Randall. 2006. The Social Implications of Basketmaker II Cordage Design Distribution. Kiva 71 (3):275-298.

Hallson, Jennifer. 2017. A Quantitative Analysis of Promontory Cave 1: An Archaeological Study on Population Size, Occupation Span, Artifact Use-life, and Accumulation. MA dissertation, Department of Anthropology, University of Alberta, Edmonton.

Honigmann, John J. 1954. The Kaska Indians: An Ethnographic Reconstruction. Yale University Publications in Anthropology 51. Human Relations Area Files Press, New Haven, Connecticut.

Ives, John W. 2014. Resolving the Promontory Culture Enigma. In Archaeology for All Time: Essays in Honor of Don D. Fowler, edited by Nancy J. Parezo and Joel C. Janetski, pp. 149-162. University of Utah Press, Salt Lake City.

Ives, John W., Duane G. Froese, Joel C. Janetski, Fiona Brock, and Christopher Bronk Ramsey. 2014. A High Resolution Chronography for Steward's Promontory Culture Collections, Promontory Point, Utah. American Antiquity 79(4):616-637.

Janetski, Joel C. 1979. Implications of Snare Bundles in the Great Basin and Southwest. Journal of California and Great Basin Anthropology 1(2):306-321.

Jennings, Jesse D. 1957. Danger Cave. University of Utah Anthropological Papers, No. 27. University of Utah Press, Salt Lake City.

Kluckhohn, Clyde, W. W. Hill, and Lucy Wales Kluckhohn. 1971. Navaho Material Culture. The Belknap Press of Harvard University Press, Cambridge.

Madsen, David B. and Steven R. Simms. 1998. The Fremont Complex: A Behavioral Perspective. Journal of World Prehistory 12(3):255-336.

Malhi, Ripan S., Holly M. Mortensen, Jason A. Eshleman, Brian M. Kemp, Joseph G. Lorenz, Frederika A. Kaestle, John R. Johnson, Clara Gorodezky, and David Glenn Smith. 2003. Native American mtDNA Prehistory in the American Southwest. American Journal of Physical Anthropology 120:108-124.

Marie, Susan and Judy Thompson. 2002. Dene Spruce Root Basketry: Revival of a Tradition. Canadian Ethnology Service, Mercury Series, No. 138. Canadian Museum of Civilization, Hull.

McBrinn, Maxine, and Cristina Peterson Smith. 2006. A New Spin on Cordage: The Effects of Material and Culture. Kiva 71(3):265-273. 
McFadyen, Annette M. 1966. Koyukuk River Culture of the Arctic Woodlands: A Preliminary Survey of Material Culture, with an Analysis of Hostility and Trade as Agents of Cultural Transmission. (Unpublished M. A. Thesis in Anthropology, George Washington University, Washington.)

McKennan, Robert A. 1959. The Upper Tanana Indians. Yale University Publications in Anthropology 55. New Haven, Conn.

- 1965. The Chandalar Kutchin. Arctic Institute of North America Technical Paper 17. Montreal.

Minar, Jill. 2001. Motor Skills and the Learning Process: The Conservation of Cordage Final Twist Direction in Communities of Practice. Journal of Anthropological Research 57(4):381-405.

Osgood, Cornelius. 1936. Contributions to the Ethnography of the Kutchin. Yale University Publications in Anthropology 14. Human Relations Area Files Press, New Haven, Conn.

- 1937. The Ethnography of the Tanaina. Yale University Publications in Anthropology 16. Human Relations Area Files Press, New Haven, Conn.

- 1970. Ingalik Material Culture. Reprinted. Human Relations Area Files Press, New Haven. Originally published 1940, Yale University Publications in Anthropology, No. 22.

.1971. The Han Indians: A Compilation of Ethnographic and Historical Data on the Alaska-Yukon Boundary Area. Yale University Publications in Anthropology 74. Human Relations Area Files Press, New Haven, Connecticut.

Peabody Museum of Archaeology and Ethnology at Harvard University. 2017. Peabody Museum Collections https://pmem.unix.fas.harvard.edu:8443/peabody/

Reilly, Aileen. 2015. Women's Work, Tools, and Expertise: Hide Tanning and the Archaeological Record. MA thesis, Department of Anthropology, University of Alberta, Edmonton.

Steward, Julian H. 1937. Ancient Caves of the Great Salt Lake Region. Smithsonian Institution, Bureau of American Ethnology, Bulletin 116. United States Government Printing Office, Washington.

Tanner, Clara Lee. 1944. Basketry of the Modern Southwest Indians. Kiva 9(3):18-26.

- 1968. Southwest Indian Craft Arts. University of Arizona Press, Tucson, Arizona.

- 1982. Apache Indian Baskets. University of Arizona Press, Tucson, Arizona.

Thompson, Judy. 1972. Preliminary Study of Traditional Kutchin Clothing in Museums. Canada. National Museum of Man, Mercury Series, Ethnology Service Paper 1. National Museums of Canada, Ottawa.

Whiteford, Andrew Hunter. 1988. Southwestern Indian Baskets: Their History and Their Makers. School of American Research Press, Santa Fe, New Mexico.
Wylie, Henry G. 1974. Promontory Pegs as Elements of Great Basin Subsistence Technology. Tebiwa 16(2):4655.

Yale Peabody Museum of Natural History. 2018. Anthropology Collection. http://collections.peabody.yale.edu. 